\title{
Exemplary Youth Leadership Series: Enable Others to Act $^{1}$
}

\section{Megan Stein ${ }^{2}$}

\section{Introduction}

This publication series is designed to outline strategies and experiences to expose youth to and engage them with leadership concepts. In this publication, students will try on aspects of the fourth practice of exemplary leaders: enabling others to act (Kouzes \& Posner, 2018). Two quick, low-cost activities are included for implementation with youth. These activities are best suited for students ages 10-18. However, modifications are included for each of the activities to allow for different group sizes, ages, and abilities of the youth participating.

\section{Enable Others to Act}

Trust is foundational when in a position of leadership. The ability to foster collaboration and strengthen others are key components of enabling others to act (Kouzes \& Posner, 2018).

The first commitment of this practice has leaders "foster collaborating by building trust and facilitating relationships" (Kouzes \& Posner, 2018, p. 14). Without trust, which allows responsibility to be shared equally, a leader can find themselves overextended and burnt out. It is important to build a strong team of leaders who believe in and share a common goal. The best way to do this is to create a coalition of trusting individuals. A climate of trust includes showing concern for others, trusting others, and being open to sharing knowledge and information.
Leaders must also "strengthen others by increasing self-determination and developing competence" (Kouzes \& Posner, 2018, p. 14). To ensure success among a team, delegate tasks to those around you. This practice allows other individuals to grow their leadership prowess and distributes responsibility among team members. It is critical for leaders to make their teammates feel capable, competent, and strong. Developing competence can also happen by giving teammates choice and allowing individuals to hold themselves accountable.

\section{Activities}

\section{Trust Builders}

Students will create an environment of trust.

Materials: Scissors, tape, pipe cleaners, paper, markers, straws, etc.

Group size: Divide the group into groups of 4-5 people.

\section{Before starting this activity:}

- Make sure you do not mention anything about trust to the students.

- Gather a list of random supplies, but make sure you have a limited quantity of everything for the size of the group.

- Create a list of tasks based on the supplies that are present. For example, cut out a green heart. Make a flag out of yellow paper and a straw. Write everyone's initials

1. This document is AEC706, one of a series of the Department of Agricultural Education and Communication, UF/IFAS Extension. Original publication date September 2020. Visit the EDIS website at https://edis.ifas.ufledu for the currently supported version of this publication.

2. Megan Stein, lecturer, Department of Agricultural Education and Communication; UF/IFAS Extension, Gainesville, FL 32611.

The Institute of Food and Agricultural Sciences (IFAS) is an Equal Opportunity Institution authorized to provide research, educational information and other services only to individuals and institutions that function with non-discrimination with respect to race, creed, color, religion, age, disability, sex, sexual orientation, marital status, national origin, political opinions or affiliations. For more information on obtaining other UF/IFAS Extension publications, contact your county's UF/IFAS Extension office. U.S. Department of Agriculture, UF/IFAS Extension Service, University of Florida, IFAS, Florida A \& M University Cooperative Extension Program, and Boards of County Commissioners Cooperating. Nick T. Place, dean for UF/IFAS Extension. 
on the flag in black marker. The number of tasks can align with the time limitations of the overall activity (i.e., more tasks, more time).

- Divide the supplies into the number of groups present. Ensure that each group does NOT have all of the materials necessary to complete the task. Only have one set of critical items (tape, scissors, etc.).

\section{Instructions:}

1. Tell the students they are in a race.

2. In a moment, they will be given a list of tasks to complete. The first team to get all of their tasks done correctly wins.

3. Hand out a list of tasks and each group's supplies.*

${ }^{\star}$ These instructions are purposely vague so students realize that they need to share resources to accomplish all tasks. This may not be immediately evident; however, students will identify this is the only means to complete the activity. Do not give them parameters on how to share or barter to ensure the task is completed.

\section{Wrap-Up Questions:}

1.How are we feeling after completing that experience?

2. Winning group-what was your strategy?

3. Could you have completed any of this on your own?

4. Did everyone share equally and honestly with each other? Why?

5. In what scenarios do we need to lean on the support of others to accomplish our tasks?

\section{Photo Scavenger Hunt}

Students will demonstrate delegation.

Materials: Smartphones or cameras

Group size: Divide the group into equal-sized teams.

\section{Instructions:}

1. Create a list of photos to take that are relatively easy to locate or find (e.g., a trash can, someone with red hair, a photo of a flower, students spelling $4-\mathrm{H}$ with their arms/ torso, etc.).

2. Tell the students they are competing against the other groups to complete the scavenger hunt.
3. Go over safety precautions or rules depending on location.

4. Give students the list.

5. The first team with all of the correct photos wins.

Modification: If smartphones or cameras are not accessible, the photos could be replaced with items.

\section{Wrap-Up Questions:}

1. The winning team - what was your strategy? Did you have one person take all of the photos or did you give each person a different task?

2. What would have happened if we gave each person a different item they were in charge of? Do you think we would have been more efficient?

3. Why is it important for us as leaders to be able to give other people tasks?

4. How can we delegate responsibilities when we are faced with challenges?

\section{Summary}

Students will engage with the fourth practice of exemplary leaders-enabling others to act. Leaders often find challenges, but they must implement solutions. These two activities help students illustrate the idea of identifying challenges and working with others to solve the problem at hand.

\section{Reference}

Kouzes, J. M., \& Posner, B. Z. (2018). The student leadership challenge: Five practices for becoming an exemplary leader. San Francisco, CA: John Wiley \& Sons. 